\title{
CORROSION BEHAVIOR OF COPPER-MODIFIED STAINLESS STEEL IN PHYSIOLOGICAL SOLUTION
}

\author{
'Žaneta GERHÁTOVÁ, ${ }^{1}, 2$ Juraj CHROMEK, ${ }^{1}$ Marián DRIENOVSKÝ, \\ ${ }^{3}$ Anka TRAJKOVSKA PETKOSKA, ${ }^{1}$ Paulína BABINCOVÁ, ${ }^{1}$ Marián PALCUT \\ ${ }^{1}$ Slovak University of Technology, Faculty of Materials Science and Technology, Trnava, Slovakia, \\ marian.palcut@stuba.sk \\ ${ }^{2}$ present address: Slovak power plants, Jaslovské Bohunice, Slovakia \\ ${ }^{3}$ University St. Kliment Ohridski-Bitola, Faculty of Technology and Technical Sciences, Veles, R. North \\ Macedonia
}

https://doi.org/10.37904/metal.2021.4196

\begin{abstract}
The microstructure, hardness, and corrosion behavior of Cu-modified austenitic stainless steels (SS) were investigated in the present work. The materials were prepared by controlled melting of SS (chemical composition Cr 22 wt. \%, Ni $9 \%$, Mo $2 \%$, Mn $2 \%$, Si 1\%, P 0.045\%, S 0.03\%, C 0.03\%, Fe bal.) with 1, 2 and 5 wt. \% Cu. The ingots were thermo-mechanically processed and annealed at $1100{ }^{\circ} \mathrm{C}$ for $30 \mathrm{~min}$. The materials were metallographically prepared by grounding and polishing for microscopy observation. The steels were found to consist of austenite matrix. A small amount of $\delta$-ferrite precipitated in the matrix during solidification. The microhardness of the materials was measured by Vickers method. The hardness of Cumodified SS was slightly reduced compared to the parent material due to $\mathrm{Cu}$ dissolution in austenite. The corrosion behavior of the steels was studied in physiological solution $(0.9 \mathrm{wt}$. $\% \mathrm{NaCl})$ by electrode polarization. A three-electrode cell controlled by potentiostat was used to monitor the progress of the reaction. Corrosion potentials were shifted to more noble values with increasing Cu concentration. The corrosion rate of SS alloyed with 2 wt. \% Cu was significantly reduced compared to the parent material. The results can be used as a guideline for an efficient design of Cu-modified SS for biomedical applications.
\end{abstract}

Keywords: Stainless steel, austenite, copper, corrosion, electrode potential

\section{INTRODUCTION}

Steels are Fe-C alloys that constitute an important group of technical materials [1]. Solubility of $\mathrm{C}$ in Fe depends on crystal modification of Fe. $\alpha$ ( $\alpha$-Fe, $\alpha$-ferrite) and $\delta$ ( $\delta$-Fe, $\delta$-ferrite) have a body-centered cubic structure $(B C C)$. The solubility of $C$ in $\alpha-F e$ and $\delta-F e$ is very low. Austenite $(y-F e)$, on the other hand, has a face-centered cubic lattice (FCC). Interstitial positions of FCC are larger than those of BCC. Therefore, the solubility of carbon in austenite is higher - up to $2.11 \%$ [1]. Austenitic stainless steels are corrosion-resistant materials alloyed with $\mathrm{Cr}$ and $\mathrm{Ni}$ [2]. These materials have high hardness and good mechanical properties. Their applications include kitchenware, chemical utensils, and surgical tools. $\mathrm{Cu}$ is an austenizer. In the steel, it can be used to substitute for nickel. The solubility of $\mathrm{Cu}$ in austenite is up to $\sim 4 \%$ and this element does not form carbides [2]. $\mathrm{Cu}$ is also added to improve the steel corrosion and creep resistance. Recently, it has been observed that Cu-bearing SS possess excellent antibacterial properties [3]. Namely, the antibacterial action of $\mathrm{Cu}$ is related to release of $\mathrm{Cu}^{2+}$ ions into aqueous media. The $\mathrm{Cu}^{2+}$ ions may easily adhere to cell membranes of microorganisms and efficiently destroy large colonies of bacteria.

The corrosion resistance of SS alloyed with Cu has been investigated by several authors [4-6]. Cu improves the resistance of $\mathrm{SS}$ to uniform corrosion. It was found to suppress an anodic dissolution of $\mathrm{SS}_{\text {in }} \mathrm{H}_{2} \mathrm{SO}_{4}$ [4]. 
The protective effect is related to $\mathrm{Cu}$ deposits that were found at the corroding site. The protective effect depends on the stability of deposited $\mathrm{Cu}$. SS is prone to pitting corrosion in chloride-containing environments $[5,6]$. Therefore, in the present work, the corrosion behavior of $\mathrm{SS}$ alloyed with $\mathrm{Cu}$ in $\mathrm{NaCl}$ solution has been studied. A physiological solution $(0.9 \mathrm{wt} . \% \mathrm{NaCl}$ in de-ionized water) was chosen to investigate the possible applications of the Cu-modified SS in biomedical field.

\section{MATERIALS AND METHODS}

Steels alloyed with $0.4,1,2$ and $5 \mathrm{wt}$ \% Cu were investigated in the present work. The materials were labelled as $\mathrm{SS}, 1 \mathrm{Cu}, 2 \mathrm{Cu}$ and $5 \mathrm{Cu}$, respectively. The chemical composition of SS is presented in Table 1. The starting materials were supplied by Camex, Měšice, Czech Republic. The Cu-modified SS were prepared by melting of SS with Cu lumps in MAM-1 arc-melter (Edmund Buehler). The melting was conducted in high purity $\mathrm{Ar}$ $(99.9999 \%)$. A piece of Ti was used as an oxygen getter Ti was melted first to remove a residual oxygen. Thereafter, pre-weighed pieces of SS and Cu were placed on a water-cooled Cu mold and instantly melted by striking an arc from a tungsten cathode. The samples were re-melted two times to improve the melt homogeneity. The ingots were homogenized at $1100^{\circ} \mathrm{C}$ for $2 \mathrm{~h}$ in Ar. Subsequently, they were cold-rolled, and recrystallization annealed in $\mathrm{Ar}$ at $1100^{\circ} \mathrm{C}$ for $30 \mathrm{~min}$. The steels were cut by diamond saw into smaller discs. The steel disks were hot mounted in a non-conducting resin. The mounted samples were ground with grade 1200 sandpaper and polished with diamond suspension down to $1 \mu \mathrm{m}$ surface roughness. The steel microstructures were observed by JEOL JSM 7600F scanning electrode microscope. The microscope was operated in secondary electron and backscatter electron imaging modes. An accelerating voltage of $15 \mathrm{kV}$ was used to generate the electron beam. The working distance was $15 \mathrm{~mm}$. The chemical composition of the materials was studied by energy-dispersive spectroscopy (EDS). The EDS analysis was operated by INCA software.

Table 1 Chemical composition of SS investigated in the present work (in wt. \%)

\begin{tabular}{|l|c|c|c|c|c|c|c|c|c|c|}
\hline & Cr & Mo & Ni & Mn & C & Si & S & P & Cu & Fe \\
\hline SS & 22.4 & 2.2 & 9.0 & 1.7 & 0.03 & 0.7 & 0.03 & 0.045 & 0.4 & Bal. \\
\hline
\end{tabular}

The hardness of the materials was studied by Vickers method on an IndentaMet 1100 microindenter (Buehler). The load was $4.903 \mathrm{~N}$ and an average of seven measurements is reported. The steels were corrosion-tested in a three-electrode cell (Sensortechnik Meinsberg). The polished steel surface played the role of the working electrode. The reference electrode consisted of $\mathrm{Ag} / \mathrm{AgCl}$ suspended in a saturated $\mathrm{KCl}$ solution. A Pt sheet $(2 \times 2 \mathrm{~mm})$ was used as counter electrode. The physiological solution was prepared by dissolving $0.9 \mathrm{wt}$ \% $\mathrm{NaCl}$ (Fisher) in de-ionized water at room temperature. The progress of the reaction was controlled by PGU 10 V-1A-IMP-S potentiostat from Jaissle Electronic Ltd. (Waiblingen, Germany). An open-circuit potential (OCP) of the samples was measured first. Subsequently, the samples were polarized in both cathodic and anodic directions from the OCP with a polarization speed of $1 \mathrm{mV} / \mathrm{s}$. The corroded steel surfaces were inspected by light microscope NEOPHOT 32 (LM).

\section{RESULTS AND DISUSSION}

The steels were found to consist of an austenite matrix $\mathrm{y}$, (Figure 1). The grains had regular shapes, and their size was $15 \pm 5 \mu \mathrm{m}$. The materials had similar microstructures. Cu alloying did not modify the grain size. A small amount of $\delta$-ferrite was found in $y$ matrix. The chemical composition of $y$ and $\delta$ is compared in Table 2. Most $\mathrm{Cu}$ was dissolved in austenite $(1.3-3.9$ wt. \%). $\delta$-ferrite contained approximately $0.6-1.3 \% \mathrm{Cu}$. In the $2 \mathrm{Cu}$ steel, $\delta$-ferrite was enriched in Mo. 


\section{ME'TAL

The hardness of the materials was studied by Vickers method. The results are presented in Table 3 . The hardness of Cu-modified materials has been slightly decreased compared to parent material. The observed decrease $(\sim 15 \%)$ is probably related to Cu dissolution in $\mathrm{Y}$-matrix.
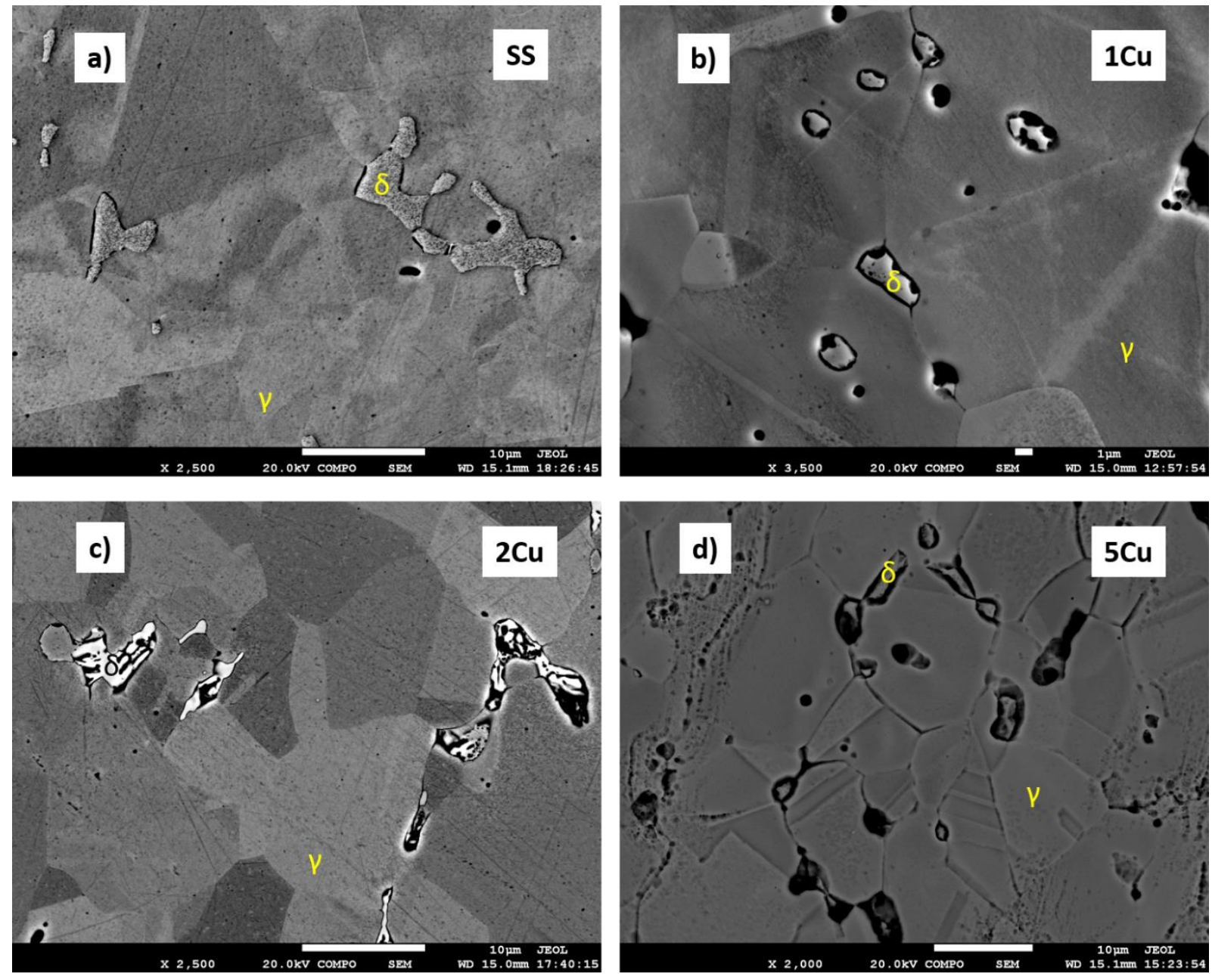

Figure 1 Microstructure of materials investigated in the present work

Table 2 Chemical composition of $y$ and $\delta$ in SS, $1 \mathrm{Cu}, 2 \mathrm{Cu}$ and $5 \mathrm{Cu}$ steels (in wt. \%)

\begin{tabular}{|c|c|c|c|c|c|c|c|c|}
\hline & $\mathrm{Cr}$ & $\mathrm{Cu}$ & $\mathrm{Ni}$ & Mo & $\mathrm{Mn}$ & Si & $s$ & $\mathrm{Fe}$ \\
\hline & \multicolumn{8}{|c|}{ SS } \\
\hline Y & 21.9 & & 9.4 & & 1.8 & 0.7 & 0.7 & 65.7 \\
\hline \multirow[t]{2}{*}{$\delta$} & 32.3 & & 3.5 & 4.5 & 1.4 & 0.8 & & 57.5 \\
\hline & \multicolumn{8}{|c|}{$1 \mathrm{Cu}$} \\
\hline Y & 20.2 & 1.3 & 9.3 & 2.0 & 1.5 & 0.6 & & 65.1 \\
\hline \multirow[t]{2}{*}{$\delta$} & 30.6 & 0.6 & 3.0 & 3.0 & 1.1 & 0.8 & & 61.0 \\
\hline & \multicolumn{8}{|c|}{$2 \mathrm{Cu}$} \\
\hline $\mathrm{Y}$ & 22.1 & 2.3 & 9.3 & 1.8 & 1.7 & 0.7 & & 49.5 \\
\hline \multirow[t]{2}{*}{$\delta$} & 35.3 & 0.6 & 3.5 & 8.7 & 1.5 & 1.0 & & 62.2 \\
\hline & \multicolumn{8}{|c|}{$5 \mathrm{Cu}$} \\
\hline Y & 20.5 & 3.9 & 8.2 & 1.8 & 1.4 & 0.6 & & 63.8 \\
\hline$\delta$ & 34.6 & 1.3 & 2.9 & 2.3 & 1.0 & 0.6 & & 57.4 \\
\hline
\end{tabular}


The corrosion resistance of the materials was studied by electrochemical methods. The steels were immersed in a freshly prepared physiological solution. OCPs were recorded immediately after sample immersion in the electrolyte. The results are compared in (Figure 2a). The OCP of $5 \mathrm{Cu}$ has significantly increased from -740 $\mathrm{mV}(\mathrm{vs}$. $\mathrm{Ag} / \mathrm{AgCl})$ at the beginning of experiment to $-290 \mathrm{mV}(\mathrm{vs} \mathrm{Ag} / \mathrm{AgCl})$ at $5 \mathrm{~min}$ of sample immersion in the electrolyte. The potentials of the remaining steels were relatively stable over time. The potentials were recorded for $30 \mathrm{~min}$. The values obtained after $30 \mathrm{~min}$ are listed in Table 3. The OCPs increase in the following order:

$\mathrm{SS} \sim 1 \mathrm{Cu}<<2 \mathrm{Cu}<5 \mathrm{Cu}$

The OCPs of the $2 \mathrm{Cu}$ and $5 \mathrm{Cu}$ steels were significantly higher compared to the parent material that indicates a smaller susceptibility of $2 \mathrm{Cu}$ and $5 \mathrm{Cu}$ steels to corrosion.
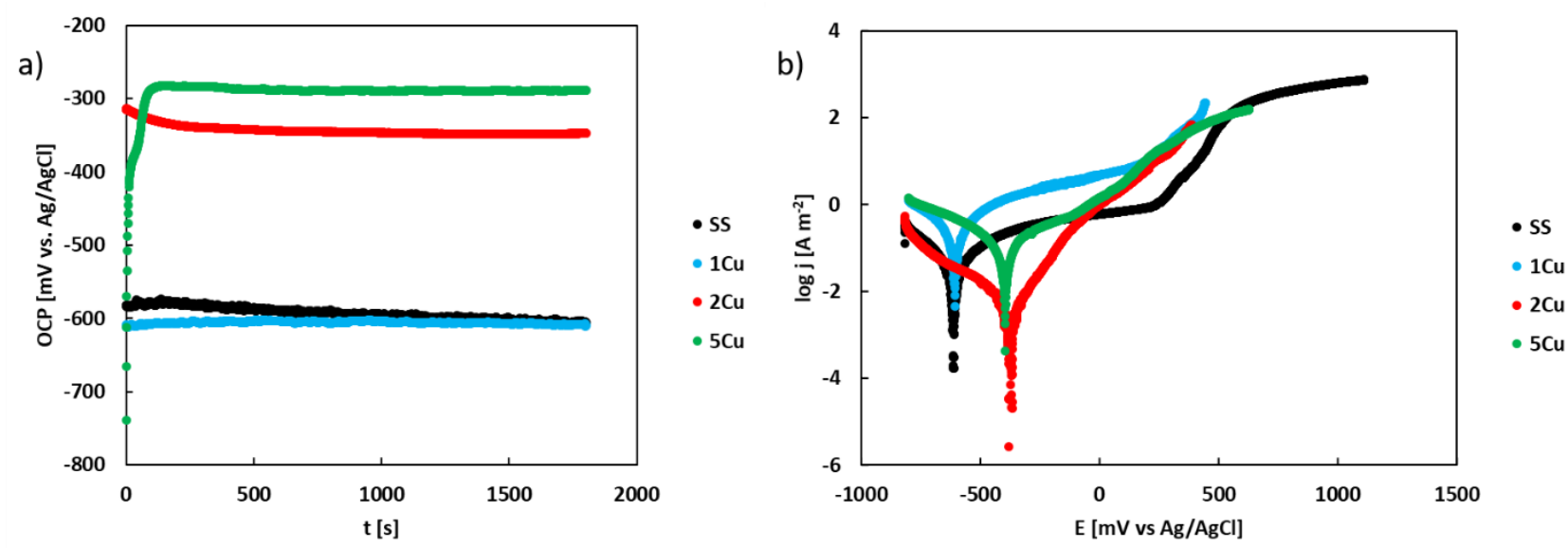

Figure 2 Open circuit potentials (a) and polarization curves (b) of Cu-bearing steels in physiological solution

Table 3 Hardness and corrosion parameters of Cu-modified steels.

\begin{tabular}{|c|c|c|c|c|c|}
\hline & Microhardness & $\mathrm{OCP}_{30 \min }$ & $E_{\text {corr }}$ & jcorr & $\mathbf{V}_{\text {corr }}$ \\
\hline & {$\left[\mathrm{HV}_{0.5}\right]$} & [mV vs. $\mathrm{Ag} / \mathrm{AgCl}]$ & [mV vs. $\mathrm{Ag} / \mathrm{AgCl}]$ & {$\left[\mathrm{A} \mathrm{m}^{-2}\right]$} & umpy \\
\hline SS & $229 \pm 3$ & -605 & -600 & $5.62 \times 10^{-2}$ & 58.7 \\
\hline $1 \mathrm{Cu}$ & $167 \pm 1$ & -608 & -610 & $20.0 \times 10^{-2}$ & 209 \\
\hline $2 \mathrm{Cu}$ & $196 \pm 6$ & -348 & -396 & $0.79 \times 10^{-2}$ & 8.3 \\
\hline $5 \mathrm{Cu}$ & $202 \pm 2$ & -289 & -420 & $11.2 \times 10^{-2}$ & 118 \\
\hline
\end{tabular}

The corrosion resistance of the materials was studied by electrode polarization in a three-electrode cell. In the experiment, a corrosion current density was measured as function of potential. The experimental polarization curves are compared in (Figure 2b). A cathodic to anodic transition at potentials close to OCP has been observed. The curves were analyzed by Tafel extrapolation [7]. Corrosion potentials, $\mathrm{E}_{\text {corr, }}$ and corrosion current densities, jcorr, obtained by this method are given in Table 3. Ecorr values of Cu-modified steels are higher compared to SS. The values approximately correspond to OCPs of the materials obtained in the previous experiment and indicate that Cu-modification leads to a significant ennoblement of the parent material.

The corrosion rate of the materials was calculated from corrosion current densities. Equation (2) based on Faraday's law, was used

$v_{\text {corr }}=\frac{E W * j_{c o r r}}{F * \rho}$ 
In this equation, EW is an equivalent weight of the steel, jcorr is the corrosion current density, $\mathrm{F}$ is a Faraday constant (95 $\left.485 \mathrm{C} \mathrm{mol}^{-1}\right)$ and $\rho$ is the steel density. EW and $\rho$ were $25.6 \mathrm{~g} \mathrm{~mol}^{-1}$ and $8000 \mathrm{~kg} \mathrm{~m}^{-3}$, respectively. The effect of chemical composition on EW and $\rho$ was negligible; therefore, identical values of $\mathrm{EW}$ and $\rho$ were used for all materials. Calculated corrosion rates are given in Table 3. The corrosion rates decrease in the following order:

$2 \mathrm{Cu}<<\mathrm{SS}<5 \mathrm{Cu}<1 \mathrm{Cu}$

The corrosion rate of the $2 \mathrm{Cu}$ steel is significantly reduced compared to SS. The corrosion rates of $1 \mathrm{Cu}$ and $5 \mathrm{Cu}$ steels are higher than the corrosion rate of SS.

The sample surfaces after corrosion were inspected by LM. The microstructures are compared in (Figure 3). A local corrosion has been observed. In the $2 \mathrm{Cu}$ steel, small and isolated pits were preferentially formed (Figure $\mathbf{3 b}$ ). In the remaining materials, the corrosion attack was more pronounced. The pits were interconnected via channels, resulting in a larger corrosion damage. This observation confirms the results obtained by electrochemical polarization, i.e., the better corrosion performance of the $2 \mathrm{Cu}$ steel compared to the rest of the materials.
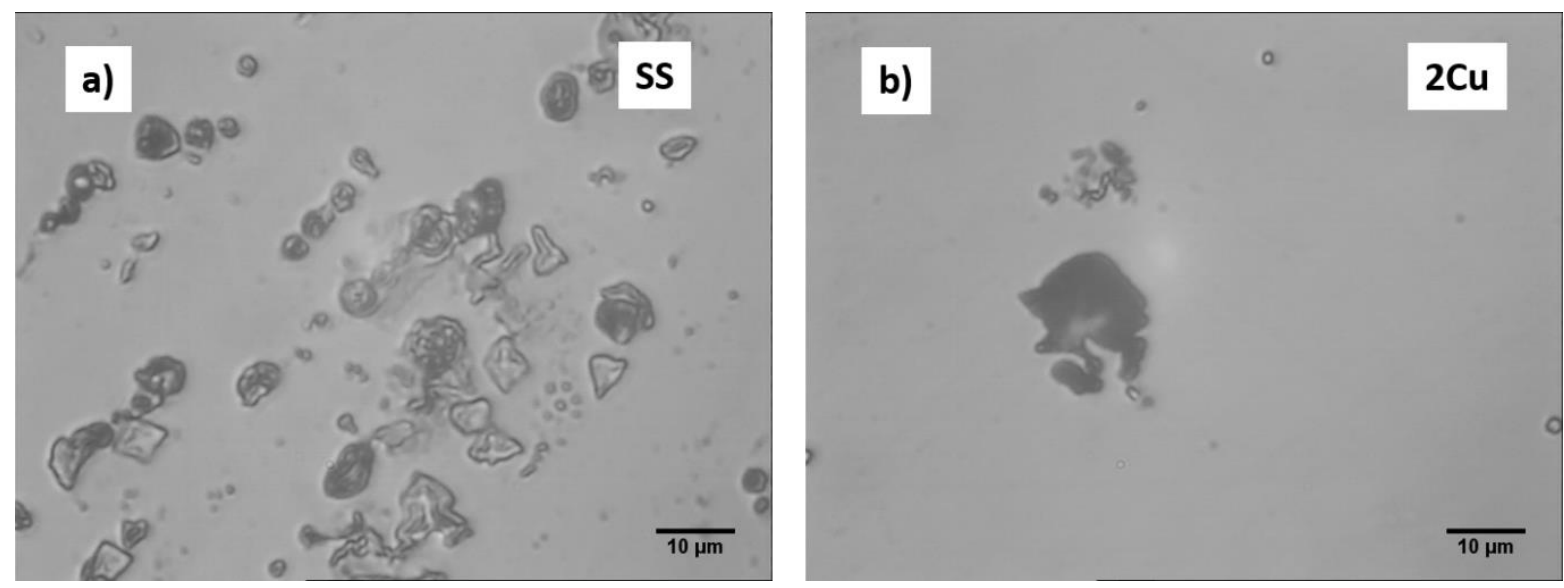

Figure 3 Sample surfaces of the parent steel (a) and 2Cu steel (b) after potentiodynamic polarization.

The results indicate that the effect of $\mathrm{Cu}$ on the corrosion behavior of $\mathrm{Cu}$-bearing stainless steel in $\mathrm{NaCl}$ is not straightforward. While it may significantly reduce the corrosion rate if used in suitable concentration ( 2 wt. \%), it may also become critical to the material. An optimization of the steel chemical composition is therefore required. The steels were composed of $y$ and $\delta$ (Figure 1). The chemical composition of $y$ and $\delta$ is compared in Table 2. Most $\mathrm{Cu}$ was dissolved in $\mathrm{y}$ which led to a significant ennoblement of this phase. $\mathrm{Cu}$ is a noble element. Its standard electrode potential is considerably higher compared to Fe - Table 3. The ennoblement activated $\gamma$ in Cu-bearing stainless steels. $y$ became cathodic with respect to $\delta$ and most probably initiated a galvanic corrosion in the materials. In the $2 \mathrm{Cu}$ steel, however, a higher concentration of Mo in $\delta$ has been found-Table 1. Mo is a ferrite stabilizer. It is a relatively noble element with electrode potential higher compared to $\mathrm{Fe}$ and $\mathrm{Cr}$-Table 3. [7] Therefore, the potential difference between $\delta$ and $\mathrm{y}$ in the 2Cu steel was smaller compared to both $1 \mathrm{Cu}$ and $5 \mathrm{Cu}$ steels. Consequently, the $2 \mathrm{Cu}$ steel was less prone to galvanic corrosion.

Table 3 Standard electrode potentials of metals [7]

\begin{tabular}{|l|c|c|c|c|c|c|}
\hline & $\mathbf{C u}$ & Mo & Ni & Fe & Cr & Mn \\
\hline $\mathrm{E}^{0}[\mathrm{mV}$ vs. SHE $]$ & +342 & -200 & -257 & -447 & -744 & -1185 \\
\hline
\end{tabular}

The Cu addition to SS in suitable concentration (2-3 wt. \%) may significantly increase the corrosion resistance in saline solution. The effect of $\mathrm{Cu}$ concentration on corrosion of $316 \mathrm{~L}$ in $0.9 \% \mathrm{NaCl}$ was previously studied 
by $\mathrm{Xi}$ et al [8]. Authors prepared two materials: 2.5 and 3.5 wt. \% $\mathrm{Cu}$. They observed that the corrosion potentials of solution treated Cu-bearing SS increased with increasing Cu concentration. The protective action of $\mathrm{Cu}$ is related to passive film formation on the surface [9]. The corrosion performance of Cu-bearing SS decreases during ageing [8]. During ageing, Cu-rich precipitates are formed. The galvanic action between Curich particles and steel matrix is significant and accelerates the corrosion rate of Cu-modified 316L SS [8]. Therefore, a precipitation of hard $\varepsilon$-Cu should be avoided.

\section{CONCLUSIONS}

In this paper the microstructure, hardness and corrosion behavior of Cu-modified stainless steels have been studied.

1) The materials were found to consist of an austenite matrix $(\mathrm{Y})$. In the matrix, a small amount of $\delta$-ferrite precipitated during solidification.

2) The hardness of the Cu-modified materials was slightly decreased compared to the parent steel. The decrease is related to $\mathrm{Cu}$ dissolution in $\mathrm{Y}$.

3) Corrosion potentials of Cu-modified SS were increasing with increasing Cu concentration.

4) The corrosion rate of SS alloyed with $2 \% \mathrm{Cu}$ was significantly smaller compared to the remaining materials. The results indicate that the effect of $\mathrm{Cu}$ on the corrosion behavior of $\mathrm{Cu}$-bearing stainless steel in $\mathrm{NaCl}$ is not straightforward. While it may significantly reduce the corrosion rate if used in suitable concentration ( $2 \mathrm{wt}$. \%), it may also become critical to the material. An optimization of the steel chemical composition is therefore required.

\section{ACKNOWLEDGEMENTS}

This work was funded by the Slovak University of Technology, grant agency VEGA of Slovak Ministry of Education project no. 1/0490/18 and Slovak Research and Development Agency project no. APVV20-0124. Prof. Mária Dománková is thanked for her useful comments on the manuscript.

\section{REFERENCES}

[1] COLÁS, R., TOTTEN, G. E. Encyclopedia of iron, steel and their alloys. CRC Press 2016.

[2] LO, K. H., SHEK, C. H., LAI, J. K. L. Recent developments in stainless steels. Materials Science and Engineering R. 2009, vol. 65, pp. 39-104.

[3] ZHANG, E.-L., FU, S., WANG, R.-X., LI, H.-X., LIU, Y., MA, Z.-Q., LIU, G.-K., ZHU, C.-S., QIN, G.-W., CHEN, D.F. Role of Cu element in biomedical metal alloy design. Rare Met. 2019, vol. 38, no. 6, pp. 476-494.

[4] PARDO, A., MERINO, M.C., CARBONERAS, M. VIEJO, F., ARRABAL, R., MUNOZ, J. Influence of Cu and Sn content in the corrosion of AISI 304 and 316 stainless steels in $\mathrm{H}_{2} \mathrm{SO}_{4}$. Corrosion Science. 2006, vol 48, pp. 1075-1092.

[5] UJIRO, T., SATOH, S., STAEHLE, R. W., SMYRL, W. H. Effect of alloying Cu on the corrosion resistance of stainless steels in chloride media. Corrosion Science. 2001, vol. 43, pp. 2185-2200.

[6] SOURISSEAU, T., CHAUVEAU E., BAROUX B. Mechanism of copper action on pitting phenomena observed on stainless steels in chloride media. Corrosion Science. 2005, vol 47, pp. 1097-1117.

[7] MCCAFFERTY, E. Introduction to corrosion science. Springer 2010.

[8] XI, T., SHAHZAD, M. B., XU, D., SUN, Z., ZHAO, J., YANG, C., QI, M., YANG, K. Effect of copper addition on mechanical properties, corrosion resistance and antibacterials proprty of $316 \mathrm{~L}$ stainless steel. Mater. Sci. Eng. C. 2017, vol 71, pp. 1079-1085.

[9] OGUZIE, E. E., LI, J., LIU, Y., CHEN, D., LI, Y., WANG, F. Electrochemical corrosion behavior of novel Cucontaining antimicrobial austenitic and ferritic stainless steels in chloride media. J. Mater. Sci. 2010, vol. 45, pp. 5902-5909. 